Business Research

Elsevier Editorial System(tm) for Journal of

Manuscript Draft

Manuscript Number: JBR-D-18-01871R2

Title: The human side of leadership: inspirational leadership effects on follower characteristics and happiness at work (HAW)

Article Type: Full length article

Keywords: Inspirational leadership; Follower characteristics; Happiness at work

Corresponding Author: Dr. ANDRES SALAS-VALLINA, Ph.D.

Corresponding Author's Institution: University of Valencia

First Author: ANDRES SALAS-VALLINA, Ph.D.

Order of Authors: ANDRES SALAS-VALLINA, Ph.D.; Cristina Simone; Rafael Fernandez-Guerrero

Abstract: Leadership has received significant attention over the past years. Now is the time to refine how leaders impact on followers and their attitudes. This study examines how inspirational leaders influence follower characteristics (FC), and in turn, their happiness at work. In this study, the mediating effect of follower characteristics in the relationship between inspirational leadership and happiness at work was specifically examined. Data was gathered from 389 frontline banking employees working in Italian and Spanish banks. A confirmatory factor analysis revealed a positive partial mediating role of follower characteristics in the relationship between inspirational leadership and happiness at work. Results showed that inspirational leadership exerts a more positive influence on followers' happiness at work when follower characteristics are more positive. Our discussion highlights the importance of understanding the role of the follower characteristics that are involved in the effectiveness of inspirational leadership. 
Detailed Response to Reviewers

Dear Editor,

Let me please mention that our paper follows JBR's formatting guidelines.

Yours faithfully,

Prof. Andrés Salas-Vallina 
The human side of leadership: inspirational leadership effects on follower characteristics and happiness at work (HAW)

Andrés Salas-Vallina (corresponding author)

Associate Professor at the University of Valencia

Av. Tarongers $s / n$

46022 Valencia (Spain)

andres.salas@uv.es

Cristina Simone

Professor at Sapienza Università Degli Studi di Roma

Via del Castro Laurenzian, 9

00161 Rome (Italy)

Rafael Fernández

Professor at the University of Valencia

Av. Tarongers. $s / n$

46022 Valencia (Spain)

The authors state no conflict of interest 


\section{The human side of leadership: inspirational leadership effects on follower characteristics and happiness at work (HAW)}

Leadership has received significant attention over the past years. Now is the time to refine how leaders impact on followers and their attitudes. This study examines how inspirational leaders influence follower characteristics (FC), and in turn, their happiness at work. In this study, the mediating effect of follower characteristics in the relationship between inspirational leadership and happiness at work was specifically examined. Data was gathered from 389 frontline banking employees working in Italian and Spanish banks. A confirmatory factor analysis revealed a positive partial mediating role of follower characteristics in the relationship between inspirational leadership and happiness at work. Results showed that inspirational leadership exerts a more positive influence on followers' happiness at work when follower characteristics are more positive. Our discussion highlights the importance of understanding the role of the follower characteristics that are involved in the effectiveness of inspirational leadership.

Keywords: Inspirational leadership; Follower characteristics; Happiness at work 


\section{The human side of leadership: inspirational leadership effects on follower characteristics and happiness at work (HAW)}

\section{Introduction}

Leadership is one of the most written-about topics in literature. Numerous books and research papers have discussed the essence, meaning and role of an effective leader (Alvesson et al., 2016; Day et al., 2014; Lukoschek et al., 2018; Newman et al., 2018;). However, leadership is becoming less ethical (Byun et al., 2018), and there is increasing interest in obtaining short-term results. Greed, selfishness, a continuous desire for more, and irreflexive and unbridled ambition would seem to be a cancerous illness at present (Neuschel, 2011), particularly in the banking industry. Over the last few years, banking firms have witnessed an important lack of professional competence (Callejas-Albiñana et al., 2017) and in the light of this situation, there may be a need to carry out organizational innovation in the sector, to move away from traditional systems to more flexible designs and relationships (Kornelakis, 2014). Along these lines, it has been suggested that the relationship between leadership style and positive attitudes (Alavi \& Gill, 2017), such as commitment and job satisfaction, are key challenges (Lu et al., 2018), in particular in the current banking sector (Belias et al., 2014). However, very few studies have examined the effects of leadership style on positive attitudes (Kopperud et al., 2014), and there is considerable uncertainty over several issues in this relationship (Belias et al., 2014). Following this, following Lu et al. (2018) logic, we argue that inspiration, a central dimension of transformational leadership which, in turn, may be a shared aspect of other leadership styles, goes some way towards explaining how leadership fosters followers' positive attitudes.

A leader must invest time and work in developing his or her intellect, which generates inspiration (Mistry \& Hule, 2015). What does it mean to be an inspirational leader? Inspirational leaders have vision and higher goals, and gain respect from and promote the participation of employees. Inspirational leadership (IL) provides meaning to needs and actions. Inspirational leaders are capable of seeing what followers need and what followers consider challenging. Dialogue, transparency and positive energy are frequently associated with IL. In contrast to ethical leadership (Walumbwa et al., 2017), IL not only demonstrates respect and fair behavior, but also provides energy, positivity 
and motivation for their followers. In this sense, prior research has shown that employee well-being depends not only on the physical work context, but also the psychosocial work environment (Gilbreath \& Benson, 2004), in which leaders play a key role. Attention has centered on determining the developmental dynamics between leadership and follower attitudes (Gardner et al., 2005). For example, Sparks et al. (2001) revealed that management style is an essential element for employee well-being. In addition, authentic leaders are likely to positively affect followers' job satisfaction (Gardner et al., 2005). Leaders are considered fundamental actors because they significantly influence employees' lives (Harris \& Kacmar, 2006). In banking services, where teamwork is fundamental, leaders need to empower followers and promote autonomy and pro-activeness among them (Hao et al., 2017). Transformational leadership has proved to positively affect followers' attitudes, such as commitment (Riaz et al., 2011) and job satisfaction (Bushra et al., 2011). However, the limitations of existing leadership styles, such as transformational and charismatic leadership, have led some researchers to focus on new modes of leadership. Since little research has explored the role of positive attitudes at work (Warr and Iceoglu, 2017) and the effects of IL on broad-based positive attitudes, the first objective of this research is to examine the effects of IL on happiness at work (HAW).

In this research, a positive, transparent and genuine IL style is likely to help followers to meet today's challenges. Inspirational leadership transmits passion to teams, makes true believers of everyone else, encourages performance, promotes certain types of behavior (Murnieks et al., 2016) and motivates followers to engage in self-sacrifice for the sake of collective goals (Howell and Shamir, 2005). Hence, IL is expected to develop followers' capabilities (Bass, 2008) and, in turn, their characteristics. On the basis of the job demands-resources theory, increased psychological resources lead to positive attitudes. Accordingly, higher levels of HAW are likely to be found. Due to all these reasons, our second objective is to check and assess the mediating role of FC in the relationship between IL and HAW. This paper is organized as follows. First, the concepts of HAW, IL and FC are reviewed. Then, methodology and results are presented. Finally, the conclusions are discussed and future research lines are suggested. 


\section{The leadership style, well-being and HAW: theoretical background}

In all ages and places, the pursuit of wellbeing seems to be one of the most constant and tenacious aims of human beings. Wellbeing has been a central concern in philosophy, psychology, sociology, medicine, law, literature and religion. Following the Second War, thanks to the huge progress in scientific and medical knowledge, the wellbeing movement began and gained increasing attention in both everyday life and scientific domains. Terms similar and/or related to the notion of wellbeing (wellness, happiness, quality of life, life satisfaction and work satisfaction) became very common. Regarding this topic, organizational literature is more and more drawing the attention of managers and scholars on the role of leadership in promoting wellbeing in workplaces and organizations. Since the seminal Hawthorne experiments (1920s-1930s) both practitioners and organizational researchers have been fascinated by the hypothesis that performance, employee's wellbeing and leadership style are mutually interdependent and reinforcing each other (Quaglino and Ghislieri, 2004). However, despite the several theoretical and empirical efforts, the pursuing of happiness and wellbeing in organizations through a specific leadership style consistent with the context still remain a challenging goal for scholars and managers (Author A). The role of team leader has radically changed, in the last years, from that of team coordinator to that of real knowledge-seeker and knowledge-creator. Team leaders, in fact, combine day-by-day capabilities, information and cognitive slack (Author B) to ensure the viability of the team, with broader qualities (e.g. leadership) to reach consensus among team members and create a collective value which is higher than the sum of single members' value (Barile et al., 2015). However, many conflicts, for example, develop out of a basic unwillingness to understand another party's interests (Fisher and Ury, 1981) (e.g. in the 
team environment, a problem can be badly exacerbated due to the essential ambiguity that exists in terms of formal and emergent channels of authority). The more profound the misalignment, the greater the likelihood of individuals and groups dividing up into "us" versus "them" encampments, which continue to promote and provoke conflict (Pinto \& Kharbanda, 1995).

The presence of these heterogeneous and multifaceted elements of conflict can generate, in absence of their careful understanding, not simply the failure of one project but also individual consequence in terms of intrinsic motivation and perceived self-efficacy (Bandura, 2007). A lack of trust, respect, effective listening skills, and perceptual differences can lead to serious communication problems. Empathy and appropriate framing abilities, therefore, are unavoidable leader's capabilities to ensure health and wellbeing of the people within the team. In order for a team to create value, in fact, team members have to be happy and engaged. For this reason, team member's engagement is considered a fundamental influencer in social value creation. If team members lose their interest in a given project or do not perceive it as important, they will not perform as well as expected, feeling disconnected. Success occurs when teams are able to work closely together to effectively solve complex problems and share the lessons learned to the rest of the organization (Author B). Thus, team leaders' communication skills - tested by overlapping areas of responsibility, gray lines of authority, delegation problems, complex project organizational structures, and conflicts among participants - assume a central role in shaping wellbeing from misunderstanding and conflict. Team leaders and their teams, in fact, must develop effective communication skills (especially listening skills) to resolve conflicts and learn how to create a positive atmosphere to gain team members' acceptance of and commitment to group goals (Verma, 1998). In this wide scenario, the role of leader is strictly related 
with the team behavior and commitment. Team leaders play the irreplaceable role of society's feelings interprets, balancing group cohesiveness and group contentiousness, pushing the personal interaction among team members and creating an atmosphere of belonging, avoiding or solving the "hidden" group pathologies (groupthink, risk shift, Asch effect, social loafing etc.). Transforming intragroup conflict into a wellbeing opportunity, therefore, is not simply a matter of information but, above all, of shared, positive feelings.

\subsection{HAW and IL: literature background and reciprocal links}

Happiness is a complex concept which involves different beliefs, moods, personal convictions and circumstances involved (Fernández et al., 2018). In the organizational field, past research developed different approaches to explain the motivational process (Herzberg et al., 1959; Kunda, 1992; Weick, 1995). The concept of happiness can be traditionally divided between hedonic happiness (pleasant feelings and favorable judgments) and eudaimonic happiness (feelings of growth and morally right attitudes). The first approach is found in research on subjective well-being, based on a preponderance of positive feelings (Schimmack, 2008). Eudaimonic well-being, in contrast, suggest that a happy life involves doing what is right and virtuous and developing skills and talents (Sheldon and Elliot, 1999). In general, happiness has been understood as global judgments of one's life, life satisfaction and low levels of negative affect (Diener et al., 1999).

The relevance of happiness at the workplace has been examined through different concepts. Fernández et al. (2018) identifies happiness with a sense of job satisfaction, in which people feel validated and their self-esteem grow. Other authors are largely focused on the hedonic experiences of pleasure and liking, and/or positive beliefs about a certain object (i.e. affective commitment); others include eudaimonic content, 
involving learning/development, growth, autonomy (i.e. self-actualization); some others focus on cognitions (beliefs and evaluative judgments) and affective phenomena (moods and emotions).

However, despite that quality of life in the workplace has been considered as essential in past academic research (Joo et al., 2017), an accurate measure for HAW is still required (Fisher, 2010). Warr (2007), for example, highlighted the redundant and large number of measures related to HAW. Moreover, Warr and Inceoglu (2012) revealed the lack of comparison between constructs related to HAW. Fisher (2010) reviewed the concept of HAW, finding that a new conceptualization of happiness at work, including both hedonic and eudaimonic components, was necessary. In this scenario, more recently, and based of Fisher's (2010) conceptualization of HAW, Author A (2017) conceptualized and measured the HAW scale. HAW is a broad, three-dimensional construct which measures the job itself, the job characteristics and the feelings of belonging to the organization, and captures both hedonism and eudaimonia, and activation and pleasure (Xanthopoulou et al.', 2012). Author's A (2017) HAW conceptualization included the constructs of engagement, job satisfaction and affective organizational commitment. Engagement is related to positive affectivity related to work, such as passion, enthusiasm or energy (Macey \& Schneider, 2008); job satisfaction refers to adequacy, sufficiency, acceptability, and judgments about work as a result of job characteristics (joy, gladness); affective organizational commitment considers affective feelings at work, and continuance and normative commitment at work. It includes affection for the organization, monetary evaluation of belonging to the organization, and feelings of responsibility to the organization. This concept refers to emotional links, identification and involvement in the organization (Meyer et al., 2002), and therefore combines the ideas of activation and pleasure. 
Research shows that the examination of the antecedents of positive attitudes is currently a hot topic (Alavi \& Gill, 2017), and this paper aims to explain the working conditions that promote employees' HAW. In particular, this research focuses on a specific leadership style, namely, IL. In addition, the possible mediating effects of FC in the relationship between IL and HAW are explored. As explained later, the jobdemands resources model supports the proposed theoretical approach.

Furthermore, it is widely accepted that the fundamental causes of HAW are the working context and the supervisor (Fisher, 2010), but further theoretical development and empirical evidence is required to better understand this process (Moynihan \& Pandey, 2007). The Job Demands-Resources (JD-R) model (Bakker \& Demerouti, 2014) argues that job resources are the physical, psychological, social, and organizational characteristics of a job which promote a motivational process, enhancing positive attitudes at work. For example, IL can be considered as a job resource, as it supports employees' development. Job demands are lack of resources (such as a lack of support from supervisors) which leads to negative states. The JD-R approach might be an accurate theoretical base to advance and improve the explanation of the relationship between leadership style and HAW. Past research evidences a lack of knowledge as to how positive attitudes are fostered in the workplace (Hackman, 2009) though some progress has been made in this area, with Breevaart et al. (2014) finding that leadership style matters when explaining positive attitudes. Leadership styles, such as transformational or authentic leadership, reveal direct effects on positive attitudes (Tims et al., 2011; Wang \& Hsieh, 2013). However, to our knowledge, no previous studies have examined the relationship between IL and a broad-ranging positive attitude in the banking services context. In fact, past research on leadership has placed little attention on examining potential connections between leadership style and positive psychology 
(Seligman et al., 2005). Rafferty \& Griffin (2004) affirm that little research has explored the effects of IL on positive attitudes. We argue that inspiration, a key characteristic of both transformational (Burns, 1978) and charismatic leaders (Bass, 1985; Shamir et al., 1993; Waldman \& Yammarino, 1999), particularly helps to predict HAW.

Among the several styles of leadership - meant as process of social influence in which the leader seeks the voluntary participation of collaborators in the effort to achieve organizational goals - enlightened by the seminal organizational literature (Black \& Mouton, 1964; Fiedler, 1967; Hersey \& Blanchard, 1969; Burns, 1978; Fiedler \& Garcia, 1987; Waldman \& Yammarino, 1999), the IL is the style according to which the leader is highly focused to empower, energize and galvanize the followers to participate actively in the organization (Bass 1990). According to this, IL is quite intertwined with the transformational leadership analyzed by Burns (1978). Transformational leadership serves to change the status quo by appealing to followers' values and their sense of higher purpose. Transformational leaders articulate the problems in the current system and have compelling vision of what a new society or organization could be. This new vision of society is intimately linked to both the leader's and followers' values; it is an ideal that is congruent with their value systems (Hughes et al., 1996: 280). Transformational leadership involves four dimensions: idealized influence, inspirational motivation, intellectual stimulation and individualized consideration (Avolio, 2005), and puts the focal point on organizational objectives (Stone et al., 2004). However, beyond the above mentioned four dimensions, transformational leadership is also characterized by a further and deeper factor: inspiration, that in turn involves communicating a vision that energizes a team (Joshi et al., 2009). Enthusiasm, confidence among subordinates (Yukl, 2013), extra effort (Howell \& Avolio, 1993), 
ethical behavior (Banerji \& Krishnan, 2000) and team trust (Joshi et al., 2009): all of them are strictly related with the IL form. A great deal of research explores the effects of transformational leadership on a variety of outcomes. However, a lack on research was found when examining the impact of the inspirational dimension of transformational leadership. In particular, the link between inspirational leadership with follower characteristics and positive attitudes, such as HAW, still remains unexplored. We state that inspiration might be the crucial factor responsible for improving followers' skills and abilities, and their HAW.

Past research has positively related transformational leadership to higher levels of followers' psychological meaningfulness and safety (Avolio, 2005), which is expected to positively affect HAW. We have based our work on Bass (1997) and Avolio's (2005) research on the full range leadership model to facilitate the explanation of the latent process through which IL is expected to influence followers' HAW. Along these lines, Sosik (2006) revealed that a leader's inspirational motivation makes followers re-think their established ways of doing things and embraces innovative procedures to deal with both common and unusual circumstances. Inspirational leaders would then be expected to boost the feeling that followers are contributing to the organization with valuable inputs. Thus, leaders who inspire are expected to increase followers' identification with their work, feelings of involvement with the job itself, therefore encouraging more positive attitudes (Sosik, 2006).

Inspiration refers to the action or power of moving the intellect or emotions (Downtown, 1973), and influences followers through affective aspects and emotional appeals at work (Bass, 1985). Compared to other leadership styles, such as authentic leadership, inspirational leadership is an attractive alternative: authenticity is not really connected with reality, as being authentic in this competitive world, particularly in the 
banking sector (under high business pressures), is not a real fact (Alvesson et al., 2016). Moreover, recent research reveals the high correlations between authentic leadership, ethical leadership and transformational leadership (Hoch et al., 2018). While servant leadership, understood as a leadership style that puts the needs of followers and stakeholders first (Greenleaf, 1977), we argue that the banking context is a complex framework to implement servant leadership, as it involves high levels of empathy, commitment to the growth of others or awareness (Spears, 2010), and reality shows that the banking culture does not promote these values. In a similar sense, the compassionate leadership style is focused on relieving pain in a benevolent loving and non-elitist way (Swann, 2002). It would be ambitious to imagine this leadership behavior in an industry where individualism, rivalry is the starting point. However, we argue that inspiration is compatible with selfishness, as it might lead, to the achievement of short term results. Inspiration is an open engine that empower employees, and positive attitudes might be the sign of this empowerment. Inspirational leadership is a more general concept compared to servant leadership or compassionate leadership. In fact, it is less altruist and just involves the power of action.

Leaders make it easy to achieve desirable goals by outlining why followers will succeed (Bass \& Bass, 2008), stimulating enthusiasm among subordinates and saying things to increase their confidence (Kabiru, 2016). An inspirational leader sets challenging objectives, provides meaning for action, appeals to feelings, envisions an attractive future and defines how to get there. Inspiration promotes passion (Murnieks et al., 2016), and makes others feel as though their concerns are considered uniquely, thus increasing their potential (Bass \& Avolio, 1990). Thus, inspirational leaders focus specifically on followers, giving them individualized consideration. Inspirational leaders foster creativity and innovation (Maladzhi \& Yan, 2014). An inspirational leader 
sets challenging objectives, uses symbols to get ideas across, provides meaning for suggested action, envisions an attractive and attainable future, and appeals to feelings (Bass, 1988). At individual level, the effects of leadership style on employees' attitudes are more evident (Yun et al., 2006). Given that employees' attitudes are determined by leadership behaviors (Liao \& Chuang, 2007), we suggest that inspirational leaders might promote HAW.

H1. IL positively and directly affects HAW

\subsection{The mediating role of follower characteristics}

Past studies have addressed the FC variable as being independent from leadership effects (Zhu et al., 2009), playing a moderating role between leadership style and its impact. Followers who show more positive characteristics are expected to strengthen the effect of a leadership style (Conger \& Kanungo, 1998). However, we argue that leaders can modify FC. For example, impulsive leaders might harm and destroy their followers and organizations (Myatt, 2013). Leadership styles such as transformational leadership broaden the interests of their employees, and develop follower capabilities (Bass, 2008). Thus, it may be particularly appropriate to examine the leadershipfollower characteristics relationship, and our research addresses the connection between IL and FC. Inspirational leaders put special emphasis on followers' emotions, and have the ability to influence followers by means of language, symbols, images and a vision of a more positive context (Bass, 1988). We define follower characteristics according to the scale proposed by Zhu et al., (2009), which involves four follower aspects: independent thinking, pro-activeness, active learning and innovativeness. Inspirational leaders attain followers' common perceived purposes through ritualistic practices that 
manage meaning and intellectually stimulate followers (Bass, 1988). This is particularly relevant because it implies that inspirational leaders might facilitate followers' independent thinking, pro-activeness, learning and innovativeness. Inspiring leaders promote autonomy (Schaufeli, 2017), which also fosters independent thinking. When followers feel euphoric and joyful thanks to inspiring leaders, they step outside their comfort zone (Bass, 1988). Inspirational leaders demonstrate social consciousness and promote it among their followers, which enhances active learning. Inspirational leaders challenge followers by modifying the way they perform their work (Sosik, 2006), stimulating learning and innovation. Following Bass (1988), inspirational leaders manage meaning and impressions, mould followers' expectations, envision, and intellectually stimulate followers. One of the consequences of transformational leadership is the professional development of followers (Dvir et al., 2002). Taking all this into account, IL is fundamental in explaining FC (Seligman et al., 2005), yet there has been little research carried out in this area.

Additionally, we argue that FC directly affects HAW. Followers have essentially remained invisible in leadership literature, even though follower characteristics play a fundamental role in the leadership-employee positive attitudes relationship (Felfe \& Schyns, 2010).

Research on HAW shows that self-esteem, locus of control and optimism are personal contributors to HAW (Lucas, 2008). These contributors are closely linked to the follower characteristics of independent thinking and proactiveness. Weierter (1997) and Bailey et al. (2014), in two meta-analyses, argued that followers with positive characteristics are more engaged at work, with engagement being a HAW dimension. 
Harter et al. (2002) stated that learning is related to positive attitudes (such as engagement). Del Libano et al. (2012) affirmed that the positive perceptions that individuals have of their personal strength and skills are favorably associated with positive attitudes. In addition, a follower's autonomy might lead to positive attitudes (Xanthopoulou et al., 2009).

In general, the JD-R model (Bakker \& Demerouti, 2014) suggests that psychological job resources promote positive attitudes, such as HAW. The Theory of Work Adjustment (Dawis \& Lofquist, 1984) argues that positive attitudes occur when working conditions meet employees' requirements. When embedded in a work context that matches followers' needs and preferences, such as the one created by inspirational leaders, individuals are expected to be happier (Fisher, 2010). Willems (2011) examined the mediating role of follower characteristics in the relationship between leadership and performance, and different models have examined the impact of leader behaviors on FC (Yukl, 1998). We are unaware of any study that has examined follower characteristics as predictors of broad-ranging positive attitudes, such as HAW.

Accordingly, and given the above, our second hypothesis is:

H2. FC mediates the relationship between IL and HAW

\section{Methods}

\subsection{Target population and sample}

Our research used a sample of 389 financial service employees, working in frontline Italian and Spanish banking services in the 5 largest banks from Spain and Italy. The average staff turnover rate of this banks was $4.83 \%$. A quantitative methodology was used, with the aim of connecting concepts in a more objective and transposable manner 
(Chiva \& Alegre, 2009). Data was gathered from June to December 2017, by means of an electronic questionnaire, in which the importance of the survey was highlighted, guaranteeing the anonymous treatment of the information given. The fundamental advantages of using electronic questionnaires are their reduced costs and immediate availability of the survey. Banking services in commercial banks are mainly provided through a wide network of branches. The organizational form of the branch is a clear vertical hierarchy, in which the branch manager, or branch director, assumes the leading role. The branch manager leads a sales team, which is responsible for reaching the branch's sales targets. This sales force (which includes managers and their followers) are under constant pressure to achieve, and all of them need extra energy to successfully get to the end of the working day. In this working context, managers need to stimulate, motivate and transmit energy to their followers, fostering their capacities so they can achieve their goals. Every employee needs to give their best in such a demanding environment.

\subsection{Measurement and methods}

To ensure maximum reliability, widely validated scales were employed in this research. The three scales that define the proposed theoretical model are presented below.

To measure IL, inspirational communication items were used from the scale adapted by Rafferty \& Griffin (2004), taken from the Podsakoff scale (Podsakoff et al., 1990). This scale is based in Bass (1985) transformational leadership concept, and it is particularly focused on subordinates' perceptions of their leaders' behavior, which makes it appropriate for the current study (Wang et al., 2005). Items revised by Grafferty \& Griffin (2004) include "Says things that make employees proud to be a part of this organization", "Says positive things about the work unit", "Encourages people to see 
changing environments as situations full of opportunities". Their work adopted a theoretically driven approach to evaluate the subdimensions of transformational leadership. According to Rafferty \& Griffin (2004), Bass (1985) inspirational leadership term refers to the employment of nonintellectual and emotional qualities to influence, and this involves a restriction of the concept. In addition, some research found an unclear structure of Bass (1985) measurement scale, raising doubts about its factorial structure (Densten, 2002). Rafferty \& Griffin (2004) underline that concerns have been raised about the inspirational leadership subdimension (Barbuto, 1997), and they conclude that the dimensions of transformational leadership have received mixed support for their differentiation. For example, Bycio et al. (1995) or Avolio et al., (1999) found problems for the fit of the Multifactor Leadership Questionnaire. Conversely, Rafferty \& Griffin (2004) developed the transformational leadership subdimension of inspirational communication, which includes the use of appeals and emotion-laden statements to stimulate follower's motivation, and demonstrates discriminant validity with the other transformational leadership subdimensions. They define inspirational communication as "the expression of positive and encouraging messages about the organization, and statements that build motivation and confidence" (Rafferty \& Griffin (2004, p. 332). The robustness of the measurement scale used in this research is demonstrated by Rafferty \& Griffin (2004), and we also empirically check the psychometric properties of this scale.

This consisted of three items, with possible responses ranging from 1 to 7 (i.e. "encourages people to see changing environments as situations full of opportunities"). Employees were asked about their perception of their leader as being inspirational. 
Employees' perceptions seem to be fundamental as the effects of leadership style are clearer when they are measured by means of followers' perceptions (Zhu et al., 2009). The FC measurement scale was adapted from the scale developed by Zhu et al. (2009). It is a Likert scale, which comprised and assessed four items, with responses ranging from 1 "totally disagree" to 7 "totally agree" (i.e. "I am willing to behave proactively"). HAW was measured using Author A (2017) Likert scale. It comprised and assessed three dimensions: engagement, job satisfaction and affective organizational commitment, with responses ranging from 1 "totally disagree" to 7 "totally agree" ("At my job, I feel strong and vigorous").

Initially, the first step was to analyze the psychometric properties of the measurement scales. An accepted methodology was followed to check dimensionality, content validity, reliability, discriminant validity and convergent validity (Gerbing \& Anderson, 1998). Then, the hypotheses of the model were examined. Both the direct and the mediating effects were checked to assess the whole theoretical model.

\section{Results}

Figure 1 shows gender and age details of the sample. The average age of the sample was 39.2, and most employees are men and women between 26 and 45 years old. In banking services, human resource policies aim to maintain a relatively young workforce, by offering early retirement to older employees. It is noteworthy that women have a greater presence in banking to the age of 46 , notably un younger ages. This is due to the increasing existence of women in university business administration degrees (which is an entry condition in the bank industry), joined with the greater presence of women in the labor market. Further, women might demonstrate better competences in this sector 
(Danzer et al., 2018). In particular, 16,10\% women vs. 23,39\% men belong to the 26-35 age range, and $15,85 \%$ women vs. $14,66 \%$ men belong to the $36-45$ age range. Table 2 shows the average and standard deviation of IL, FC and HAW.

\section{INSERT FIGURE 1 ABOUT HERE}

Figure 1. Sample details of gender and age

\subsection{Psychometric properties}

To assess the psychometric properties, dimensionality, reliability and content, convergent and discriminant validity were checked. Confirmatory factor analysis (CFA) was performed to evaluate the unidimensionality of the measurement scales of AL, FC and HAW (Table 1). The properties of the IL construct confirmed its unidimensionality $(\mathrm{p}$-value $>.05 ; \mathrm{BBNFI}=0.952 ; \mathrm{CFI}=0.989 ; \mathrm{RMSEA}=0.043) . \mathrm{FC}$ also revealed its unidimensionality $(\mathrm{p}$-value $>.05 ; \mathrm{BBNFI}=0.995 ; \mathrm{CFI}=0.997 ; \mathrm{RMSEA}=0.049)$. Although the RMSEA of the Shortened Happiness at Work scale (SHAW) was slightly over 0.08 , results indicated the unidimensionality of this construct $(\mathrm{BBNFI}=0.991$; CFI $=0.989)$.

Content validity was ensured because the measurement scales used in this study had been empirically validated in prior research. Coefficient alpha and composite reliability were obtained to guarantee scale reliability (Bou-Llusar et al., 2009). In Table 2, Cronbach Alphas and composite reliability results indicated acceptable values (above $0.70)$. 
The BBNFI indicator was used to check convergent validity. All BBNFI values and factorial loads for each construct (see Table 1) were over the recommended value of 0.90 (Hair et al., 2006). Hence, convergent validity was demonstrated. Table 2 shows factor correlations, means, standard deviations, Cronbach's alphas and composite reliabilities.

Discriminant validity was checked following Fornell-Larcker criterion. The average variance extracted (AVE) of each latent variable was higher than the squared correlation between the constructs (Henseler et al., 2009), which let as confirm discriminant validity.

\section{INSERT TABLE 1 ABOUT HERE}

Table 1. Goodness-of fit of the measurement scales

\section{INSERT TABLE 2 ABOUT HERE}

Table 2. Factor correlations, means, standard deviations, Cronbach's alphas and composite reliabilities of measurement scales. IL = Inspirational leadership; FC = Follower characteristics; SHAW = Shortened happiness at work measurement scale. *Statistically significant correlation coefficient $\mathrm{p}<0.05$; Cronbach's alphas are shown on the diagonal. Composite reliabilities (CR) are shown in the CR column.

\subsection{Analysis of hypotheses}

Zhao et al. (2010) recommendations were followed to evaluate the mediating effect of FC on the relationship between IL and HAW (Table 3). 
Figures 2 and 3 show a positive and significant relationship in the direct effect model ( $\alpha$ $=.296, \mathrm{t}=5.108, \mathrm{p}<.01)$. The results enable us to affirm that the fit of the structural model is good, and therefore H1 can be accepted.

In addition, the FC construct plays a partial mediating role in the relationship between IL and HAW. This means that FC improves the explanation of HAW. The mediating model (Figure 2) reveals a higher $\mathrm{R}^{2}(.540)$ than the direct effect model (.311), which means that the mediating model explains the dependent variable better. Therefore, while the direct effect relationship between IL and HAW is still significant, FC improves the explanatory capacity of the mediating model (and Figure 3). Therefore, FC exerts partial mediation, and H2 can be accepted (Tippins and Sochi, 2003).

A bootstrap estimation was performed based on 500 bootstrap samples. The bootstrap outputs in the indirect effect model show that the indirect effect of IL on HAW through FC is statistically significant and different from zero. In consequence, according to Preacher and Hayes (2004), our hypothesis of mediation is supported (Table 3).

In addition, Harman's single factor test was performed to identify common method variance. A percentage of the variance of 0.173 was found explained by the single factor. In consequence, a non-significant amount of common variance was found.

\section{INSERT FIGURE 2 ABOUT HERE}

Figure 2. Direct effect model

The item loadings were all significant $p<0.001$. (1) The parameter was equaled to 1 to fix the latent variable scale. The T-values are shown in brackets. $\mathrm{IL}=$ Inspirational leadership; HAW = Happiness at Work 


\section{INSERT FIGURE 3 ABOUT HERE}

Figure 3. Mediation model

The item loadings were all significant $p<0.01$. (1) The parameter was equaled to 1 to fix the latent variable scale. T-values are shown in brackets. IL = Inspirational leadership; FC = Follower characteristics; HAW = Happiness at Work

\section{INSERT TABLE 3 ABOUT HERE}

Table 3. Test results of partial mediation effect: the mediating role of FC (follwers characteristics) on the relationship between IL (inspirational leadership) and HAW (happiness at work). $* * * p \leq .001, * * p \leq .01$, $* \mathrm{p} \leq .05$

\section{Discussion}

This study has examined the role that inspirational leaders play on followers' HAW. In addition, our model has examined the mediating role of FC in the relationship between IL and HAW. Our aim was to extend the knowledge surrounding IL, FC and HAW and check it empirically in a business sample in which leadership is fundamental, namely, frontline banking employees. The financial crisis has influenced a whole host of working aspects in many countries around the world. Many adjustments in human resource designs have affected banking firms and, as a result, diverse studies have focused on the relationship between leadership and positive attitudes (i.e. job satisfaction, commitment, etc.) (Belias \& Koustelios, 2014). The interaction between leaders and followers has become crucial, and many leadership styles have aimed to explain how leaders influence followers. The human side of leadership is fundamental in this context. 
First, we have contributed to the literature by identifying the fact that IL can influence followers' HAW. As such, rather than focusing on task-related motivation, we have stressed the importance of the relationship between leaders and followers. Empirical evidence was found to corroborate the direct and positive effect of IL on HAW. Furthermore, we answered both the challenges that had arisen in Fisher's (2010) review and put paid to the inconsistent findings (Belias et al., 2014) that questioned the leadership-positive attitudes relationship in order to examine what boundary conditions leaders might set to promote followers' HAW. Therefore, our second contribution consisted of providing evidence that FC mediate the relationship between IL and HAW. Inspirational leaders reshape followers' attributes (FC) and, in turn, FC affect followers' HAW. We defined FC as independent thinking, pro-activeness, active learning and innovativeness. Results have revealed that inspirational leaders directly and positively affect FC. Inspirational leaders intellectually stimulate followers, and this is used by inspiring leaders to enhance subordinate independence and autonomy, as Bass (1988, p.28) affirms: "Instead of being given the fish, subordinates learn how to fish for themselves". Followers are encouraged to use intelligence to overcome obstacles when inspired by leaders, who also encourage followers to leave their comfort zone (Bass, 1988). Followers' active learning derives from the intellectual stimulation provided by inspirational leaders. Inspirational leaders are also able to imagine a broad vision of things and to envision them beyond basic material profit. As Einstein wrote, imagination is more important than knowledge, because knowledge focuses on all that is, while imagination points to all there will be. Envisioning a desired future and showing how to get there is a key factor of the inspirational process, which moves followers towards creativity, and thus towards innovation, by creating alternative possible solutions (Bass, 1988). Therefore, FC is conditioned by the IL style. These 
follower characteristics also exert a direct effect on HAW. Our results are in line with Cheng \& Furham (2004), who revealed that self-esteem, which is a sign of followers' independent thinking or pro-activeness, improves happiness. Autonomy, which is a concept that is also closely connected with independent thinking and pro-activeness, improves intrinsic motivation (Inauen, 2014). This type of motivation is related to the HAW dimension of engagement. Author A (2017) also empirically demonstrated that learning positively affects an employee's HAW. Innovative behavior has also been linked to increased positive attitudes (Yean et al., 2016). In sum, the four-dimension follower characteristics concept used in this research has shown that it directly influences followers' HAW.

From a practical perspective, our findings suggest that leaders might need to pay closer attention to followers. Leaders who promote responsibility and authority among followers will enhance their followers' quality of life at work, namely, HAW. IL might help followers to identify new ideas to achieve their objectives or improve their performance. In high pressure working contexts, sales forces with robust personal resources are fundamental, and IL has proved that it fosters FC. Our results also show that companies should bear in mind followership and leadership training. Positive followership training becomes essential, as well as making sure followers and leaders have coincident perceptions of FC. In general, we suggest that followers have more potential of which their leaders are unaware, and we conclude that both organizations and leaders might improve followers' HAW by simply believing in them.

\section{Final remarks: limitations, managerial challenges and future research paths}

Our findings need to be understood in the light of the limitations related to the nature of the research. First, we cannot determine the direction of causality among our constructs. 
However, we did conduct supplementary interviews, which met with past theory and research evidence (Kark et al., 2003). This evidence has led us to believe that IL influences FC and HAW. Second, our results are based on the responses of employees who work in a specific sector. One may therefore argue that these findings are contextually limited and thus are not appropriate in other contexts. However, the positive relationship between IL, FC and HAW is in accordance with findings made in prior research in different business sectors and contexts (Bass, 1988; Joshi et al., 2009). Third, this research is developed at the individual level, and recent works introduce a multilevel perspective in the JD-R framework (Bakker and Demerouti, 2018). Therefore, we suggest that a multilevel approach can bring significant findings to advance in the leadership and positive attitudes literature.

Beyond the specific aims and limits of this work, in this final remarks we would like to underline that as humans spend much of their life at work, the relationship among ILFC-HAW, in turn, affects both the individual and organizational performances and the individual and social well-being (Author B, 2018). Practitioners and scholars are increasingly aware of the crucial relationship among IL, FC and HAW in terms of worrying risks and costs related to an organizational misbehavior (i.e., bullying behavior, mobbing, burn-out, unfair discrimination): health problems, lower job satisfaction, lower job performance, decreased productivity, reduced creativity, distrust, increased turn-over and absenteeism, increase in conflicts and legal disputes. Worrying risks and costs because of which the organization is likely to collapse. However, despite the several theoretical and empirical efforts, understanding and promoting virtuous feedback loops among IL-FC-HAW still remain challenging goals for scholars and managers: they imply not linear paths. Indeed, over the last decades, the challenges to occupational well-being have become more and more harder because of the dramatic 
changes of work conditions. The rise of globalization, the intensification of strategic competition, the need for a more flexible workforce and the related fear of job insecurity: all together these changes have shaped a more a more unpredictable environment. Under these conditions, the relationship among leaders and their followers becomes, at the same time, more and more crucial to keep pace and to save the organizational effectiveness and more and more complex to be effectively managed. In this view, further researches are required to deeper understand the complex and crucial feedback loops among IL-FC-HAW. In particular, future researches should investigate the (virtuous or vicious) influence of the organizational cultural model (assumptions, beliefs, values, rules etc.) on the relationship IL-FC-HAW together with the role of the structural features of the organization (span of control, level of standardization, main coordination mechanisms, systems of job evaluation, rewards and careers etc.). Moving from the extant researches in this field, future researches should contribute to understand the still "hidden" dynamics of the not linear feedback loop among IL-FCHAW. Above all, they should be helpful in reducing the risk that the organizational attempts to promote HAW via IL are likely to fail or to be not credible in the every-day work-life due to some neglected organizational dimensions. Absenteeism, conflict, job satisfaction, creativity and trust are not simply matter of information-sharing and accomplished tasks, they are also a matter of social empathy, communication and emotional contagion: "you cannot drive someone you do not understand. He can be commanded, bribed, cajoled or prodded...but he cannot be guided, if you have no idea of who he is" (Dilts, 1990). 


\section{References}

Alavi, S. B., \& Gill, C. (2017). Leading Change Authentically: How Authentic Leaders Influence Follower Responses to Complex Change. Journal of Leadership \& Organizational Studies, 24(2), 157-171.

Alvesson, M., Blom, M., \& Sveningsson, S. (2016). Reflexive Leadership: Organising in an imperfect world. London: Sage.

Avolio, B. J. (2005). Leadership development in balance: Made/born. Mahwah, NJ: Lawrence Erlbaum.

Avolio, B. J., Bass, B. M., \& Jung, D. I. (1999). Re-examining the components of transformational and transactional leadership using the Multifactor Leadership Questionnaire. Journal of Occupational and Organizational Psychology, 72, 441-462.

Baas, M., De Dreu, C. K. W., \& Nijstad, B. A. (2008). A meta-analysis of 25 years of mood-creativity research: hedonic tone, activation, or regulatory focus. Psychological Bulletin, 134(6), 779-806.

Bakker, A. B., Demerouti, E., \& Sanz-Vergel, A. I. (2014). Burnout and work engagement, The JD-R approach. Annual Review of Organizational Psychology and Organizational Behaivor, 1(1), 389-411.

Bakker, A.B., \& Demerouti, E. (2018). Multiple levels in job demands-resources theory: Implications for employee well-being and performance. Handbook of wellbeing. Salt Lake City, UT: DEF Publishers. DOI: nobascholar.com.

Bandura, A. (2007). Auto-efficacité: le sentiment d'efficacité personnelle. Paris: De Boeck. 
Banerji, P., \& Krishnan, V.R. (2000) Ethical preferences of transformational leaders: An empirical investigation. Leadership \& Organization Development Journal, 21(8), 405-413.

Barbuto, J.E. (1997) Taking the charisma out of transformational leadership. Journal of Social Behavior and Personality, 12(3), 689-697.

Barsade, S.G., Ward, A.J., Turner, J.D.F., \& Sonnenfeld, J.A. (2000) To your heart's content, A model of affective diversity in top management teams. Administrative Science Quarterly, 45, 802-836.

Bass, B.M. (1985) Leadership and Performance beyond Expectations. New York: Free Press,

Bass, B. M., \& Avolio, B.J. (1990). The implications of transactional and transformational leadership for individual, team and organizational development. Research in Organizational Change and Development, 4, 231-272.

Bass, B. M. (1997). Does the transactional-transformational leadership paradigm transcend organizational and national boundaries? American psychologist 52(2), 130139.

Bass, B. M. (1998). Transformational Leadership: Industrial, military and educational impact. State University of New York at Binghamton.

Bass, B. M., \& Bass, R. (2008). The Bass Handbook of Leadership. New York: Free Press.

Black, R. R., \& Mouton, J. S. (1964). The Managerial Grid. Houston: Gulf.

Breevaart, K., Bakker, A., Hetland, J., Demerouti, E., Olsen, O. K. , \& Espevik, R. (2014). Daily transactional and transformational leadership and daily employee engagement. Journal of occupational and organizational psychology, 87(1), 138-157.

Belias, D., \& Koustelios, A. (2014). Transformational leadership and job satisfaction in the banking sector: A review. International Review of Management and Marketing, 4(3), 187-200.

Belias, D., Koustelios, A., Koutiva, M., Thomos, A., Sdrolias, L., \& Zournatzi, E. (2014). Demographics of Greek Bank Employees' Motivation Characteristics. In 9th Annual MIBES International Conference, Perrotis College, Thessaloniki 30th May 1st June.

Bou-Llusar, J. C., Escrig-Tena, A. B., Roca-Puig, V., \& Beltrán-Martín, I. (2009). An empirical assessment of the EFQM Excellence Model: Evaluation as a TQM framework relative to the MBNQA Model. Journal of Operations Management, 27(1), 1-22.

Burns, J. M. (1978). Leadership. New York: Harper \& Row. 
Bushra, F., Ahmad, U., \& Naveed, A. (2011). Effect of transformational leadership on employees' job satisfaction and organizational commitment in banking sector of Lahore (Pakistan). International journal of Business and Social Science, 2(18), 261-267.

Bycio, P., Hackett, R. D., \& Allen, J. S. (1995). Further assessments of Bass' 1985 conceptualization of transactional and transformational leadership. Journal of Applied Psychology, 80(4), 468-478.

Byun, G., Karau, S. J., Dai, Y., \& Lee, S. (2018). A three-level examination of the cascading effects of ethical leadership on employee outcomes: A moderated mediation analysis. Journal of Business Research, 88, 44-53.

Callejas-Albiñana, F. E., Martínez-Rodríguez, I., Callejas-Albiñana, A. I., \& de Vidales-Carrasco, I. M. (2017). Assessing the growth of ethical banking: Some evidence from Spanish customers. Frontiers in Psychology, 8, 1-12.

Cheng, H., \& Furnham, A. (2004). Perceived parental rearing style, self-esteem and self-criticism as predictors of happiness. Journal of Happiness Studies, 5(1), 1-21.

Chiva, R., \& Alegre, J. (2009). Organizational learning capability and job satisfaction: An empirical assessment in the ceramic tile industry. British Journal of Management, 20(3), 323-340.

Conger, J. A., \& Kanungo, R. N. (1998). Charismatic leadership in organizations. Thousand Oaks, CA: Sage.

Day, D. V., Fleenor, J. W., Atwater, L. E., Sturm, R. E., \& McKee, R. A. (2014). Advances in leader and leadership development: A review of 25 years of research and theory. The Leadership Quarterly, 25(1), 63-82.

Dawis, RV, \& Lofquist, LH (1984). A psychological theory of work adjustment: An individual-differences model and its applications. University of Minnesota Press, Minnesota.

Del Libano, M, Llorens, S, Salanova, M, \& Schaufeli, WB (2012). About the dark and bright sides of self-efficacy: workaholism and work engagemen'. The Spanish Journal of Psychology, 15(2), 688-701.

Densten, I. L. (2002). Clarifying inspirational motivation and its relationship to extra effort. Leadership \& Organization Development Journal, 23(1), 40-44.

Diener, E., Suh, E. M., Lucas, R. E., \& Smith, H. L. (1999). Subjective well-being: three decades of progress. Psychological Bulletin, 125(2), 276-302.

Dilts, R. (1990). Changing Belief Systems With NLP. Meta Publications.

Downton, J. V. (1973). Rebel leadership: Commitment and charisma in the revolutionary process. The Free Press, New York. 
Dvir, T., Eden, D., Avolio, B. J. \& Shamir, B. (2002). Impact of transformational leadership on follower development and performance: A field experiment. Academy of management journal, 45(4), 735-744.

Downtown, J. V. (1973). Rebel leadership: Commitment and charisma in a revolutionary process. New York: Free Press.

Felfe, J., \& Schyns, B. (2010). Followers' personality and the perception of transformational leadership: further evidence for the similarity hypothesis. British Journal of Management, 21(2), 393-410.

Fernández, J. L. F., Gamez, M. A. F., de Querol Aragón, N., \& Gil, A. C. (2018). Happiness at work, Business behaviour and worker Perceptions: a case Study. Ramon Llull Journal of Applied Ethics, 8, 33-64.

Fiedler, FE (1967). Theory of Leadership Effectiveness. New York: McGraw-Hill.

Fiedler, F. E., \& Garcia, J. E. (1987). New Approaches to Leadership: cognitive resources and Organizational Performance. New York: Wiley.

Fisher, C. (2010). Happiness at work. International Journal of Management Reviews 12(4), 384-412.

Fisher, R, \& Ury, W. (1981). Getting to Yes: Negotiating Agreement Without Giving In. New York: Houghton Mifflin.

Fornell, C., \& Larcker, D. F. (1981). Evaluating Structural Equation Models with Unobservable Variables and Measurement Error. Journal of Marketing Research, 18(1), 39-50.

Gardner, H. (1983). Frames of Mind. New York: Basic Books.

Gardner, W. L., Avolio, B. \& Walumbwa, F. (2005). Authentic leadership development: Emergent trends and future directions. In W. L. Gardner, B. J. Avolio, \& F. O. Walumbwa (Eds.), Authentic leadership theory and practice: Origins, effects and development (pp. 387-406). Oxford, UK: Elsevier Science

Gerbing, D. W., \& Anderson, J. C. (1988). An updated paradigm for scale development incorporating unidimensionality and its assessment. Journal of Marketing Research, 25(2), 186-192.

Gilbreath, B., \& Benson, P. G. (2004). The contribution of supervisor behaviour to employee psychological wellbeing. Work \& Stress, 18(3), 255-266.

Greenleaf, R. K. (1977). Servant-leadership: A journey into the nature of legitimate power and greatness. Mahwah, NJ: Paulist Press.

Hackman, J. R. (2009). The perils of positivity. Journal of Organizational Behavior, 30(2), 309-319. 
Hair, J. F. Jr., Black, W. C., Babin, B. J., Anderson, R. E., \& Tatham, R. L. (2006). Multivariate Data Analysis. New Jersey: Prentice Hall.

Hao, P., Wei, H., \& Li-Rong, L. (2017). Why and When Empowering Leadership Has Different Effects on Employee Work Performance: The Pivotal Roles of Passion for Work and Role Breadth Self-Efficacy. Journal of Leadership \& Organizational Studies, in press. https://doi.org/10.1177/1548051817707517

Harris, K. J., \& Kacmar, K. M. (2006). Too much of a good thing: The curvilinear effect of leader-member exchange on stress. The Journal of social psychology, 146(1), 65-84.

Harrison, D. A., Newman, D. A., \& Roth, P. L. (2006). How important are job attitudes? Meta-analytic comparisons of integrative behavioral outcomes and time sequences. Academy of Management Journal, 49(2), 305-325.

Harter, J. K., Schmidt, F. L., \& Hayes, T. L. (2002). Business-unit-level relationship between employee satisfaction, employee engagement, and business outcomes: A metaanalysis. Journal of Applied Psychology, 87(2), 268-279.

Hatfield, E., Cacioppo, J. T., \& Rapson, R. L. (1993). Emotional contagion. Current Directions in Psychological Sciences, 2, 96-99.

Henseler, J., Ringle, C. M., \& Sinkovic, R. R. (2009). The use of Partial Least Squares Path Modeling in international marketing. Advances in International Marketing, 20, 277-320.

Hersey, P., \& Blanchard, K. H. (1969). Life Cycle Theory of Leadership. Training and Development Journal, 23, 26-34.

Howell, J. M., \& Avolio, B. J. (1993). Transformational leadership, transactional leadership, locus of control, and support for innovation: Key predictors of consolidatedbusiness-unit performance. Journal of applied psychology, 78(6), 891-902.

Howell, J. M., \& Shamir, B. (2005). The role of followers in the charismatic leadership process: Relationships and their consequences. Academy of Management Review, 30(1), 96-112.

Hughes, R. L., Ginnett, R. C., \& Curphy, G. J. (1996). Leadership. Enhancing the Lessons of Experience, $2^{\text {nd }}$ ed. Chicago: Irwin.

Inauen, E. (2014). How the approval of rules influences motivation. Evidence-based HRM: a Global Forum for Empirical Scholarship, 2(1), 96-113.

Joo, B. K., Joo, B. K., Lee, I., \& Lee, I. (2017). Workplace happiness: Work engagement, career satisfaction, and subjective well-being. Evidence-based HRM: a Global Forum for Empirical Scholarship, 5(2), 206-221. 
Joshi, A., Lazarova, M. B., \& Liao, H. (2009). Getting everyone on board: The role of inspirational leadership in geographically dispersed teams. Organization Science, 20(1), 240-252. doi:10.1287/Orsc.1080.0383.

Kharbanda, O. P., \& Stallworthy, E. A. (2004). Il lavoro in team. La struttura piramidale è fallita. Come organizzare e guidare gruppi di lavoro nella nuova impresarete (n. 82). FrancoAngeli, Roma.

Kura, K. M. (2016). Linking Environmentally Specific Transformational Leadership and Environmental Concern to Green Behaviour at Work. Global Business Review, 17(3), 1S-14S.

Kopperud, K. H., Martinsen, Ø., \& Humborstad, S. I. W. (2014). Engaging leaders in the eyes of the beholder: On the relationship between transformational leadership, work engagement, service climate, and self-other agreement. Journal of Leadership \& Organizational Studies, 21(1), 29-42.

Kornelakis, A. (2014). Liberalization, flexibility and industrial relations institutions: evidence from Italian and Greek banking. Work, employment and society, 28(1), 40-57.

Liao, H., \& Chuang, A. (2007). Transforming service employees and climate: a multilevel, multisource examination of transformational leadership in building longterm service relationships. Journal of Applied Psychology, 92(4), 1006-1019.

Lu, X., Xie, B., \& Guo, Y. (2018). The trickle-down of work engagement from leader to follower: The roles of optimism and self-efficacy. Journal of Business Research, 84, 186-195.

Lukoschek, C. S., Gerlach, G., Stock, R. M., \& Xin, K. (2018). Leading to sustainable organizational unit performance: Antecedents and outcomes of executives' dual innovation leadership. Journal of Business Research, 91, 266-276.

Lucas, R. E. (2008). Personality and subjective wellbeing. In Eid, M. \& Larsen, R.J. (Eds), The Science of Subjective Well-Being (171-194). New York: The Guilford Press.

Macey, W. H., \& Schneider, B. (2008). The meaning of employee engagement. Industrial and Organizational Psychology, 1(1), 3-30.

Maladzhi, R. W., \& Yan, B. (2014). Effect of inspirational and motivational leadership on creativity and innovation in SMEs. In Industrial Engineering and Engineering Management (IEEM), 2014 IEEE International Conference on (pp. 1433-1437). IEEE.

Meyer, J. P., Stanley, D. J., Herscovitch, L., \& Topolnytsky, L. (2002). Affective, continuance, and normative commitment to the organization: A meta-analysis of antecedents, correlates, and consequences. Journal of vocational behavior, 61(1), 20-52.

Mistry, J., \& Hule, M. A. (2015). Inspirational Leadership. Prin. LN Welingkar Institute of Management Development \& Research, 8. 
Moynihan, D. P., \& Sanjay, K. P. (2007). Finding Workable Levers over Work Motivation: Comparing Job Satisfaction, Job Involvement, and Organizational Commitment. Administration \& Society, 39(7), 803-832.

Murnieks, C. Y., Cardon, M. S., Sudek, R., White, T. D., \& Brooks, W.T. (2016). Drawn to the fire: The role of passion, tenacity and inspirational leadership in angel investing. Journal of Business Venturing, 31(4), 468-484.

Myatt, M. (2013). A crisis of leadership - what's next? Forbes. Retrieved from http://www.forbes.com/sites/ mikemyatt/2013/10/10/a-crisis-of- leadership-whats-next/

Neuschel, R. (2005). The servant leader: Unleashing the power of your people. Evanston, Illinois: Northwestern University Press.

Newman, A., Herman, H. M., Schwarz, G. \& Nielsen, I. (2018). The effects of employees' creative self-efficacy on innovative behavior: The role of entrepreneurial leadership. Journal of Business Research, 89, 1-9.

Pinto, JK, \& Kharbanda, O. P. (1995). Project management and conflict resolution. Project Management Journal, 26(4), 45-54.

Posner, B. Z. (1986). What's All the Fighting About? Conflicts in Project Management. IEEE Transactions on Engineering Management, 33, 207-211.

Rafferty, A. E., \& Griffin, M. A. (2004). Dimensions of transformational leadership: Conceptual and empirical extensions. The Leadership Quarterly, 15(3), 329-354.

Podsakoff, P. M., MacKenzie, S. B., Moorman, R. H., \& Fetter, R. (1990). Transformational leader behaviors and their effects on followers' trust in leader, satisfaction, and organizational citizenship behaviors. The leadership quarterly, l(2), 107-142.

Preacher, K. J., \& Hayes, A. F. (2004). SPSS and SAS procedures for estimating indirect effects in simple mediation models. Behavior research methods, instruments, \& computers, 36(4), 717-731

Quaglino, G., \& Ghislieri, E. C. (2004). Avere leadership. In The conquest of happiness, Raffaello Cortina and Russell, B. A. W. (Eds.) (pp. 1-138).

Riaz, T., Akram, M. U., \& Ijaz, H. (2011). Impact of transformational leadership style on affective employees' commitment: An empirical study of banking sector in Islamabad (Pakistan). The Journal of Commerce, 3(1), 43-51.

Schaufeli, W. B. (2017). Applying the Job Demands-Resources model. Organizational Dynamics, 2(46), 120-132.

Sahmir, B., House, R. J., \& Arthur, M. (1993). The Motivational Effects of Charismatic Leadershhip: A self-Concept Based Theory. Organizaiton Science, 4(4), 577-594. 
Sheldon, K. M., \& Elliot, A. J. (1999). Goal striving, need satisfaction, and longitudinal well-being: the self-concordance model. Journal of Personality and Social Psychology, 76, 482-497.

Seligman, M. E., Steen, T. A., Park, N., \& Peterson, C. (2005). Positive psychology progress. American psychologist, 60(5), 410-421.

Sahmir, B., House, R. J., \& Arthur, M.B. (1993). The Motivational Effects of Charismatic Leadershhip: A self-concept based theory. Organizaiton Science, November, 4(4), 577-594.

Schoenewolf, G. (1990). Emotional contagion: Behavioral induction in individuals and groups. Modern Psychoanalysis, 15, 49-61

Siengthai, S., \& Pila-Ngarm, P. (2016). The interaction effect of job redesign and job satisfaction on employee performance. Evidence-based HRM: a Global Forum for Empirical Scholarship, 4(2), 162-180.

Sosik, J. J. (2006). Full range leadership: Model, research, extensions and training. In C. Cooper \& R. Burke (Eds.), Inspiring leadership (pp. 33-66). New York: Routledge.

Sparks, K., Faragher, B., \& Cooper, C. L. (2001). Well-being and occupational health in the 21st century workplace. Journal of occupational and organizational psychology, 74(4), 489-509.

Stone, G. A., Russell, R. F., \& Patterson, K. (2004). Transformational versus servant leadership: A difference in leader focus. Leadership \& Organization Development Journal, 25(4), 349-361.

Sy, T., Cote, S., \& Saavedra R. (2005). The Contagious Leader: Impact of the Leader's Mood on the Mood of Group Members, Group Affective Tone, and Group Processes. Journal of Applied Psychology, 90(2), 295-305.

Swann, R. (2002). Compassion in school leadership (pp. 1-15). Australian Council for Educational Leaders. Monograph 31.

Thamhain, H. J., \& Wilemon, D. L. (1977). Leadership, Conflict, and Program Management Effectiveness. Sloan Management Review, 19(1), 69-89.

Tims, M., Bakker, A. B., \& Xanthopoulou, D. (2011). Do transformational leaders enhance their followers' daily work engagement? Leadership Quarterly, 22(1), 121-131.

Verma, V. K. (1998). Conflict Management. The Project Management Institution. Jeffrey Pinto: Project Management Handbook.

Waldman, D. A., \& Yammarino, F. J. (1999). CEO Charismatic Leadership: Levels of Management and Levels of Analysis Effects. Academy of Management Review, 24(2) 266-285. 
Walumbwa, F. O., Hartnell, C. A., \& Misati, E. (2017). Does ethical leadership enhance group learning behavior? Examining the mediating influence of group ethical conduct, justice climate, and peer justice. Journal of Business Research, 72, 14-23.

Wang, D., \& Hsieh, C. (2013). The effect of authentic leadership on employee trust and employee engagement. Social Behavior and Personality, 41(4), 613-624.

Wang, H., Law, K. S., Hackett, R. D., Wang, D., \& Chen, Z. X. (2005). Leader-member exchange as a mediator of the relationship between transformational leadership and followers' performance and organizational citizenship behavior. Academy of management Journal, 48(3), 420-432.

Warr, P. (2007). Work, Happiness, and Unhappiness. Mahwah, NJ: Lawrence Erlbaum.

Warr, P., \& Inceoglu, I. (2012). Job engagement, job satisfaction, and contrasting associations with person-job fit. Journal of Occupational Health Psychology, 17(2), 129-138.

Warr, P., \& Inceoglu, I. (2017). Work orientations, well-being and job content of selfemployed and employed professionals. Work, employment and society, in press.

Weierter, S. J. M. (1997). Who wants to play "follow the leader"? A theory of charismatic relationships based on routinized charisma and follower characteristics. Leadership Quarterly, 8(2),171-193.

Willems, V (2011) An Authentic Approach to Leadership and Performance: The Mediating Role of Follower Trust. (Master Thesis, School of Business and Economics, Maastricht University).

Xanthopoulou, D., Bakker, A. B., Heuven, E., Demerouti, E., \& Schaufeli, W. B. (2008) Working in the sky: a diary study on work engagement among flight attendants. Journal of Occupational Health Psychology, 13(4), 345-356.

Xanthopoulou, D., Bakker, A. B., Demerouti, E., \& Schaufeli W. B. (2009). Reciprocal relationships between job resources, personal resources, and work engagement. Journal of Vocational Behavior, 74(3), 235-244.

Xanthopoulou, D., Bakker, A. B., \& Ilies, R. (2012). Everyday working life: Explaining within-person fluctuations in employee well-being. Human relations, 65(9), 1051-1069.

Yukl, G. (2010). Leadership in organizations (3rd custom edition for Royal Roads University). Upper Saddle River, NJ: Prentice Hall.

Yun, S., Cox, J. \& Sims, Jr. H. P. (2006). The forgotten follower: a contingency model of leadership and follower self-leadership. Journal of Managerial Psychology, 21(4), 374-388.

Zhao, X., Lynch, Jr. J. G., \& Chen, Q. (2010) Reconsidering Baron and Kenny: Myths and truths about mediation analysis. Journal of consumer research, 37(2), 197-206. 
Zhu, W., Avolio, B. J., \& Walumbwa, F. O. (2009). Moderating role of follower characteristics with transformational leadership and follower work engagement. Group \& Organization Management, 34(5), 590-619.

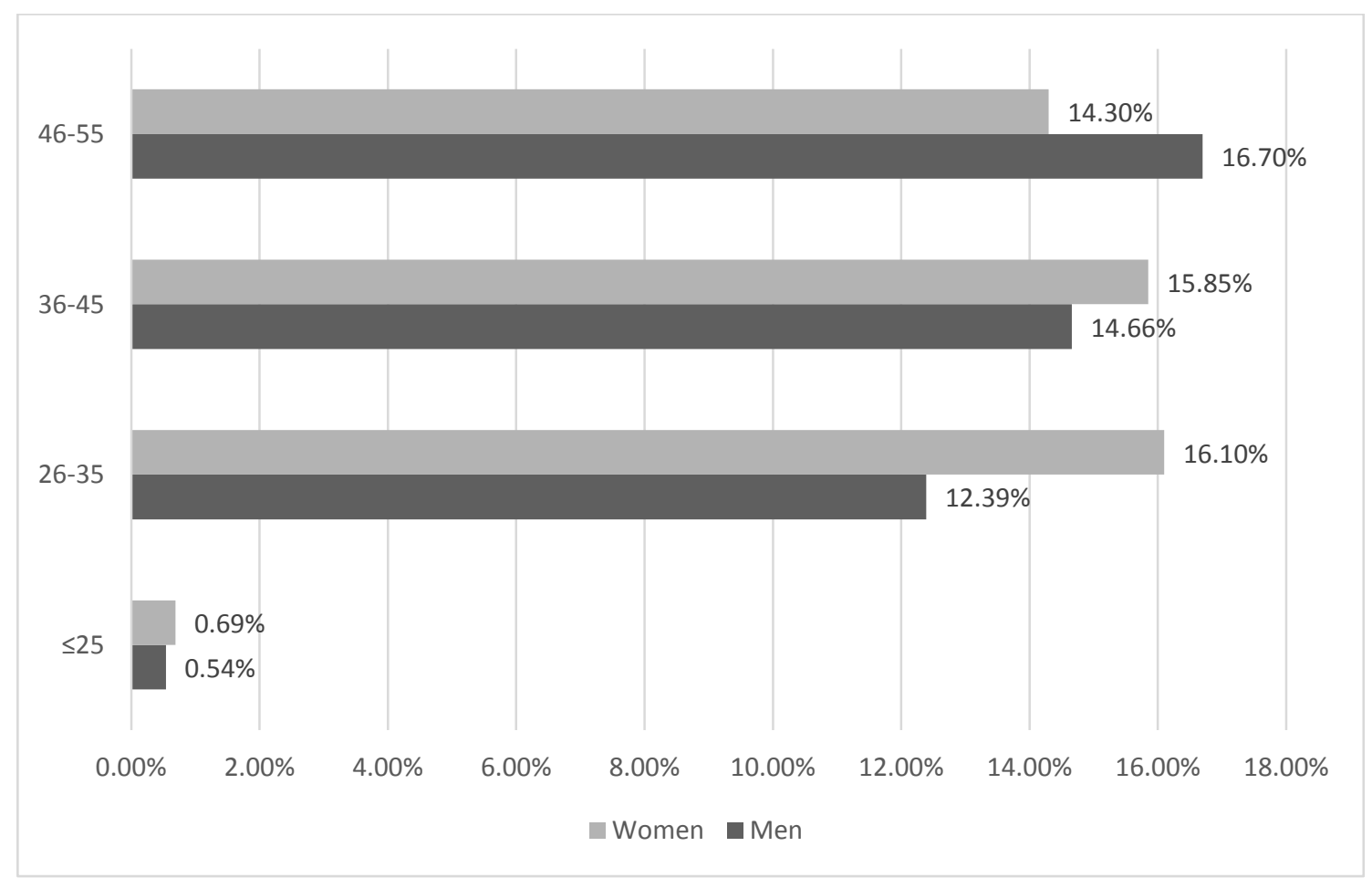


Figure 1. Sample details of gender and age

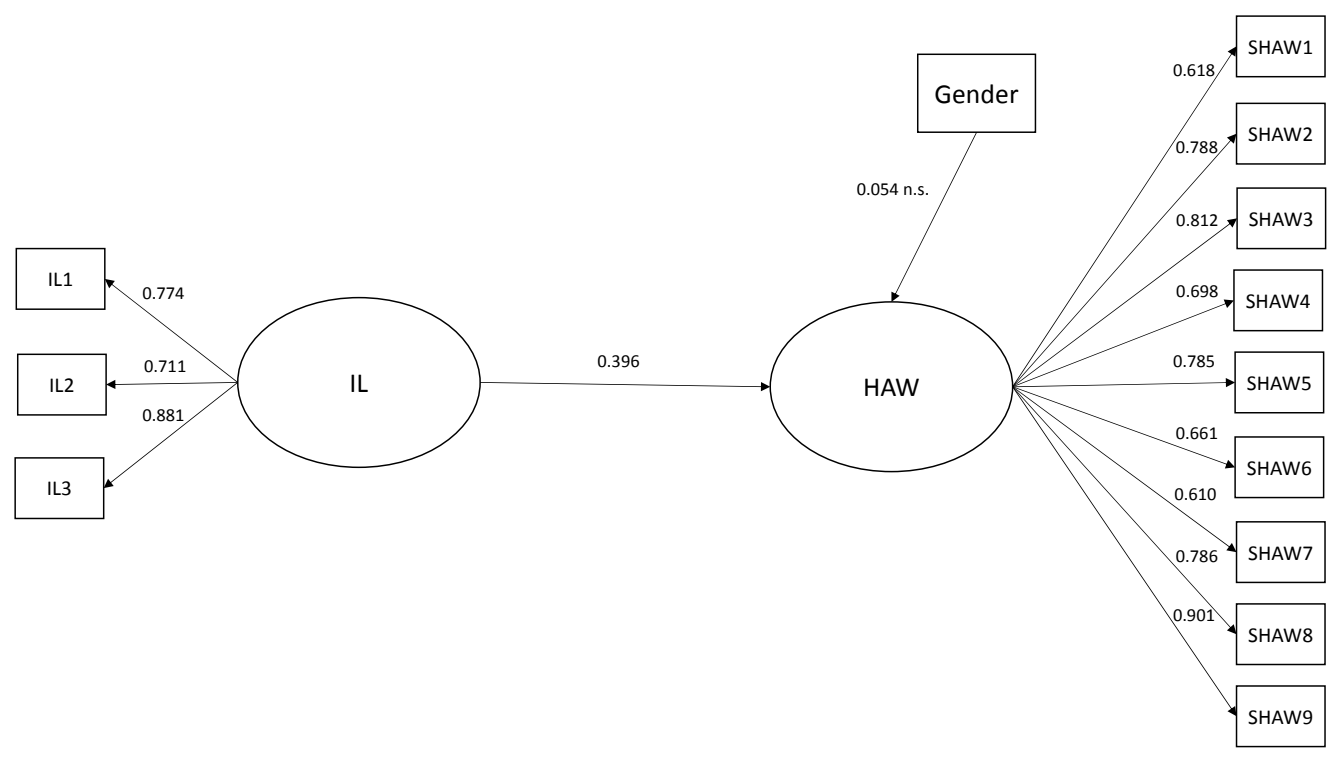

Figure 2. Direct effect model

The item loadings were all significant $p<0.001$. (1) The parameter was equaled to 1 to fix the latent variable scale. The T-values are shown in brackets. IL = Inspirational leadership; HAW = Happiness at Work. 


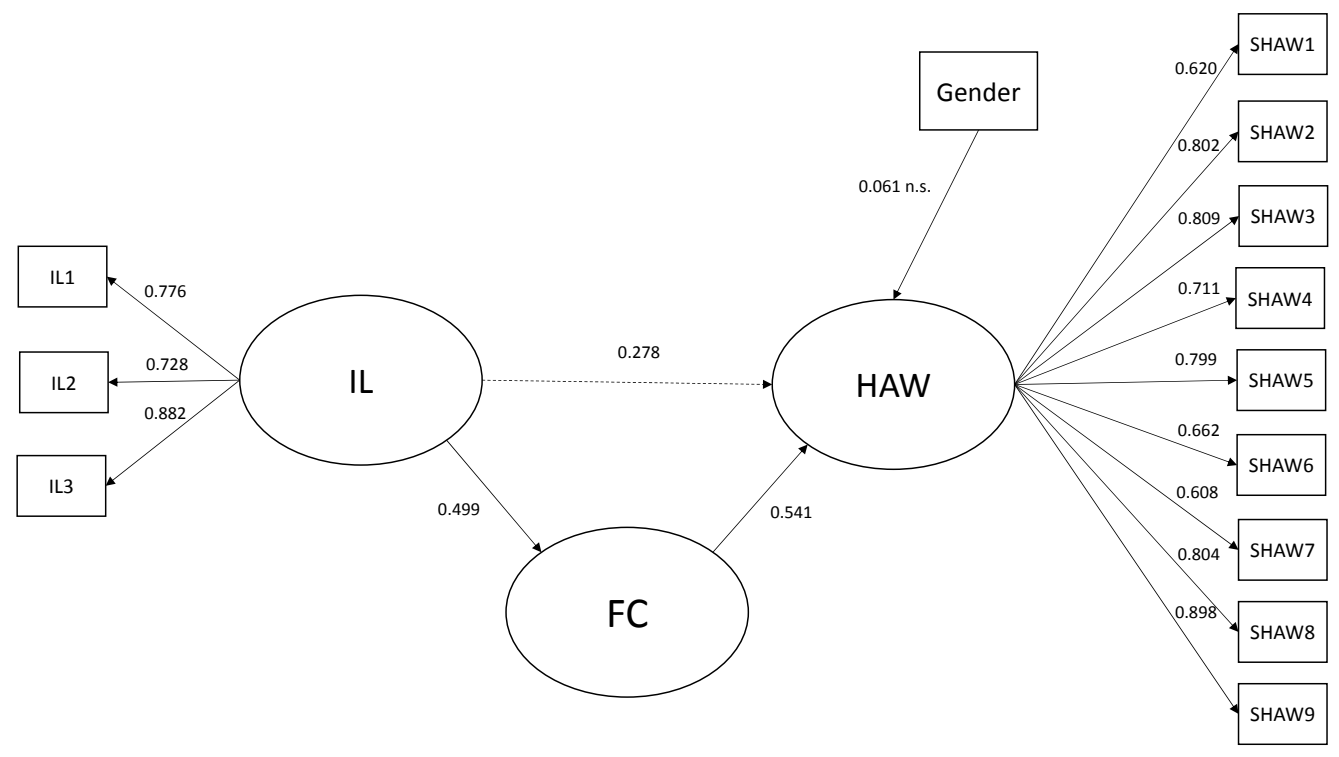

Figure 3. Mediation model

The item loadings were all significant $p<0.01$. (1) The parameter was equaled to 1 to fix the latent variable scale. T-values are shown in brackets. IL = Inspirational leadership; FC = Follower characteristics; HAW = Happiness at Work.

\begin{tabular}{llllllll}
\hline \hline Mod. & S-B $\boldsymbol{\chi 2}$ & d.f. & p-value & BBNFI & CFI & RMSEA & NC $(=\boldsymbol{\chi 2}$ /d.f. $)$ \\
\hline IL & 8.432 & 3 & 0.039 & 0.952 & 0.989 & 0.043 & 2.811 \\
& & & & & & & \\
FC & 7.545 & 6 & 0.044 & 0.995 & 0.997 & 0.049 & 1.258 \\
& & & & & & & 1.980 \\
\hline
\end{tabular}

Table 1. Goodness-of fit of the measurement scales

\begin{tabular}{lllllll}
\hline \hline & Mean & s.d. & CR & JS & LU & CSP \\
\hline 1. IL & 3.618 & 1.432 & 0.839 & $(0.821)$ & & \\
2. FC & 4.136 & 1.804 & 0.878 & $0.63^{*}$ & $(0.833)$ & \\
3. SHAW & 4.002 & 1.514 & 0.975 & $0.69^{*}$ & $0.71^{*}$ & $(0.904)$ \\
\hline \hline
\end{tabular}


Table 2. Factor correlations, means, standard deviations, Cronbach's alphas and composite reliabilities of measurement scales. IL = Inspirational leadership; FC = Follower characteristics; SHAW = Shortened happiness at work measurement scale. *Statistically significant correlation coefficient $\mathrm{p}<0.05$; Cronbach's alphas are shown on the diagonal. Composite reliabilities (CR) are shown in the CR column.

\begin{tabular}{llllll} 
& & & & \multicolumn{2}{c}{ Percentile } \\
\cline { 5 - 6 } & Coefficient & S.E. & T-value & Lower & Upper \\
\hline Total effect & & & & & \\
IL -> HAW & $0.396^{* * *}$ & 0.02 & 112.15 & & \\
Direct effect & & & & & \\
IL -> HAW & $0.278^{* * *}$ & 0.01 & 58.24 & & \\
IL -> FC & $0.499^{* * *}$ & 0.02 & 122.06 & & \\
FC -> HAW & $0.541^{* *}$ & 0.01 & 136.34 & & \\
GENDER -> HAW & 0.061 n.s. & 0.0 & 0.02 & & \\
& & & & & \\
Indirect effect & & & & & \\
IL -> HAW & $0.224 *$ & 0.01 & 15.28 & 0.11 & 0.22 \\
IL -> FC -> HAW & $0.121^{*}$ & 0.01 & 7.42 & 0.07 & 0.16 \\
\hline
\end{tabular}

Table 3. Test results of partial mediation effect: the mediating role of FC (follwers characteristics) on the relationship between IL (inspirational leadership) and HAW (happiness at work). $* * * p \leq .001, * * p \leq .01$, $* p \leq .05$ 
Figure 1

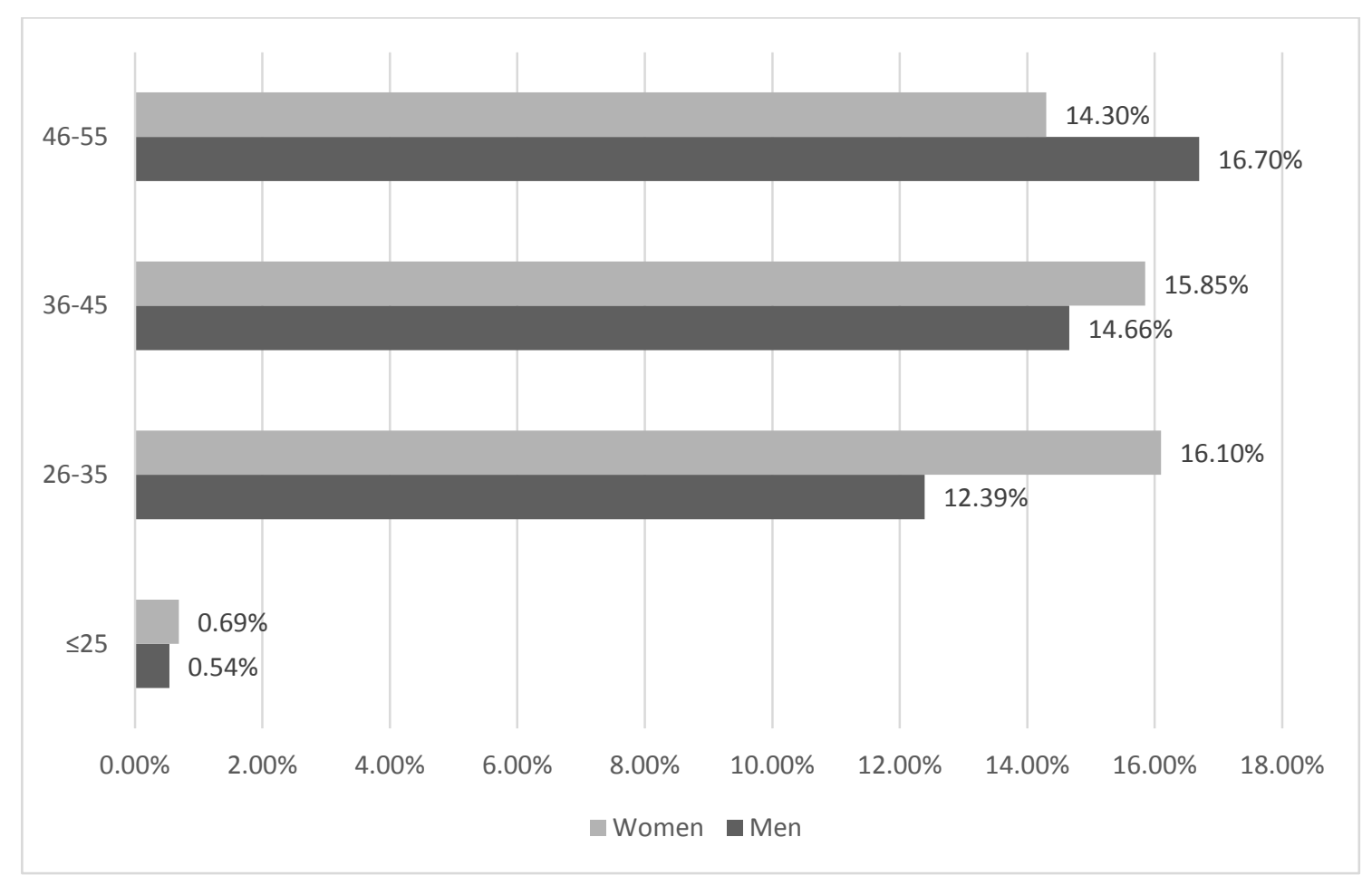

Figure 1. Sample details of gender and age 


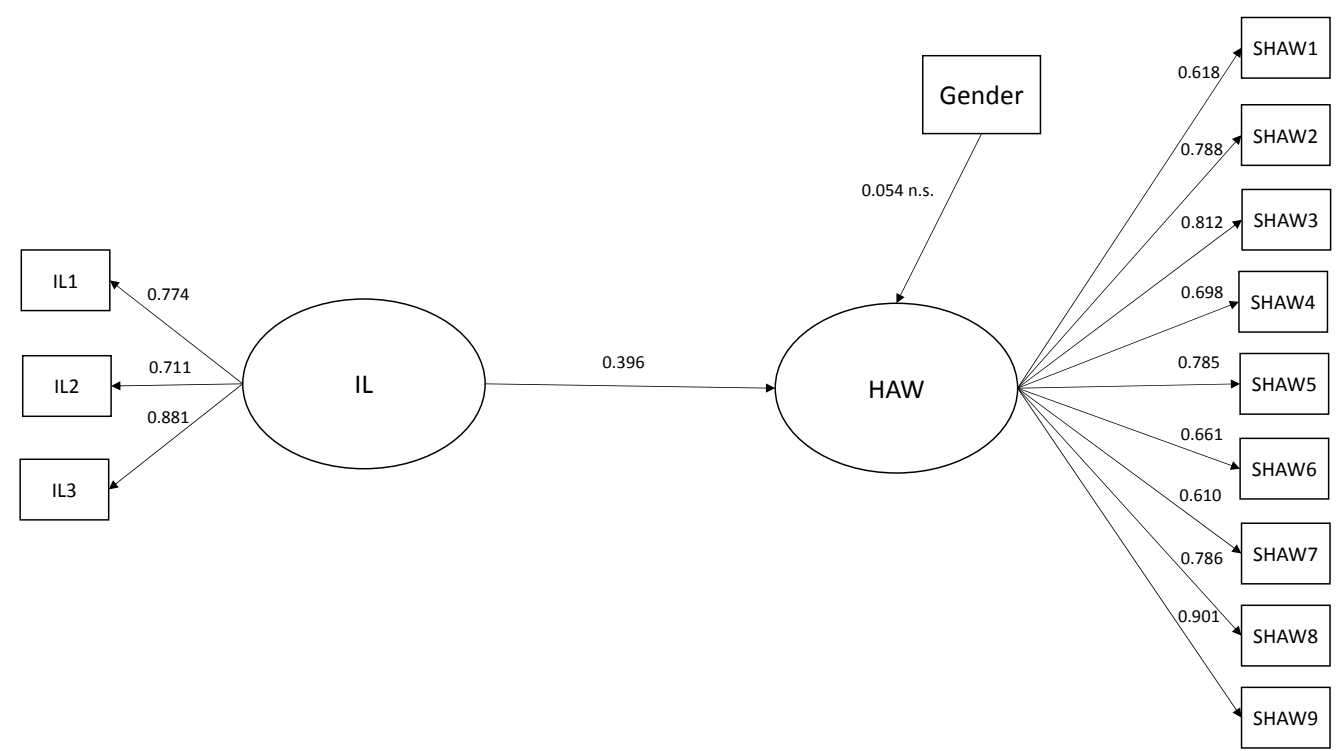

Figure 2. Direct effect model

The item loadings were all significant $p<0.001$. (1) The parameter was equaled to 1 to fix the latent variable scale. The T-values are shown in brackets. IL = Inspirational leadership; HAW = Happiness at Work 


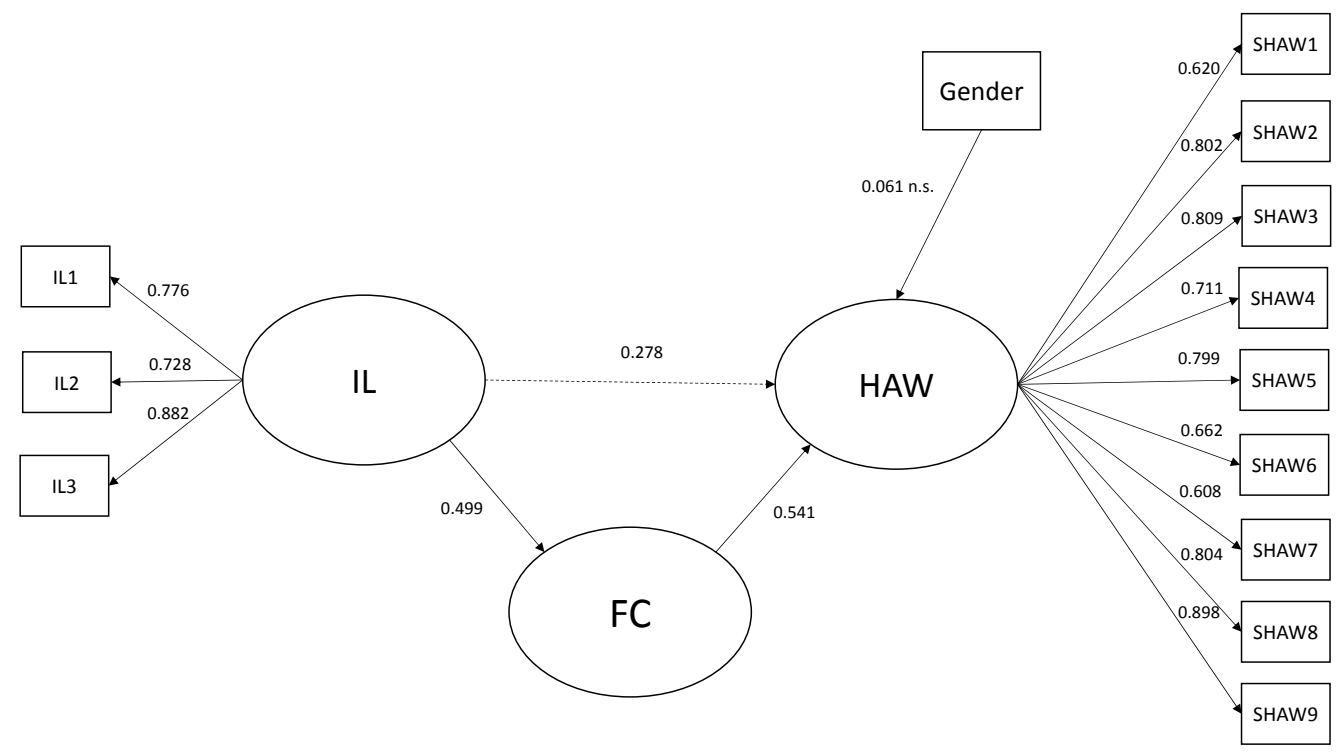

Figure 3. Mediation model

The item loadings were all significant $p<0.01$. (1) The parameter was equaled to 1 to fix the latent variable scale. T-values are shown in brackets. IL = Inspirational leadership; $\mathrm{FC}=$ Follower characteristics; HAW = Happiness at Work 


\begin{tabular}{llllllll}
\hline \hline Mod. & S-B $\chi \mathbf{2}$ & d.f. & p-value & BBNFI & CFI & RMSEA & NC (= $\chi 2$ /d.f. $)$ \\
\hline IL & 8.432 & 3 & 0.039 & 0.952 & 0.989 & 0.043 & 2.811 \\
FC & 7.545 & 6 & 0.044 & 0.995 & 0.997 & 0.049 & 1.258 \\
& & & & & & & \\
SHAW & 45.545 & 23 & 0.018 & 0.991 & 0.989 & 0.089 & 1.980 \\
\hline \hline
\end{tabular}

Table 1. Goodness-of fit of the measurement scales 


\begin{tabular}{lllllll}
\hline \hline & Mean & s.d. & CR & JS & LU & CSP \\
\hline 1. IL & 3.618 & 1.432 & 0.839 & $(0.821)$ & & \\
2. FC & 4.136 & 1.804 & 0.878 & $0.63^{*}$ & $(0.833)$ & \\
3. SHAW & 4.002 & 1.514 & 0.975 & $0.69 *$ & $0.71^{*}$ & $(0.904)$ \\
\hline \hline
\end{tabular}

Table 3. Factor correlations, means, standard deviations, Cronbach's alphas and composite reliabilities of measurement scales. IL = Inspirational leadership; FC = Follower characteristics; SHAW $=$ Shortened happiness at work measurement scale. *Statistically significant correlation coefficient $\mathrm{p}<0.05$; Cronbach's alphas are shown on the diagonal. Composite reliabilities (CR) are shown in the CR column. 


\begin{tabular}{lllrll} 
& & & \multicolumn{2}{c}{ Percentile } \\
\cline { 5 - 7 } & Coefficient & S.E. & T-value & Lower & Upper \\
\hline Total effect & & & & & \\
IL -> HAW & $0.396^{* * * *}$ & 0.02 & 112.15 & & \\
Direct effect & & & & & \\
IL -> HAW & $0.278^{* * * *}$ & 0.01 & 58.24 & & \\
IL -> FC & $0.499^{* * *}$ & 0.02 & 122.06 & & \\
FC -> HAW & $0.541^{* *}$ & 0.01 & 136.34 & & \\
GENDER -> HAW & 0.061 n.s. & 0.0 & 0.02 & & \\
& & & & & \\
Indirect effect & & & & & \\
IL -> HAW & $0.224^{*}$ & 0.01 & 15.28 & 0.11 & 0.22 \\
IL -> FC -> HAW & $0.121^{*}$ & 0.01 & 7.42 & 0.07 & 0.16 \\
\hline
\end{tabular}

Table 3. Test results of partial mediation effect: the mediating role of FC (follwers characteristics) on the relationship between IL (inspirational leadership) and HAW (happiness at work). ***p $\leq .001, * * \mathrm{p} \leq .01$, $* \mathrm{p} \leq .05$ 
Data in Brief
Click here to download Data in Brief: dataprofile.xml Click here to download Data in Brief: dataprofilexml

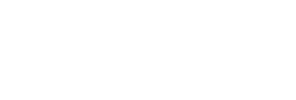

$\sqrt{2}$

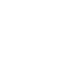

$\sqrt{2}$

(1)

(1)

(1)

(1)

(1)

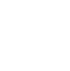
(1) . . . . . . . . . .

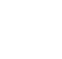




\section{The human side of leadership: inspirational leadership effects on follower characteristics and happiness at work (HAW)}

Andrés Salas-Vallina is an Associate Professor in Business Management at the Department of Management 'Juan José Renau Piqueras' at the University of Valencia. His research is focused on positive attitudes at work, organisational learning and leadership. He has published his research at journals such as Personnel Review, Employee Relations, International Journal of Manpower or International Journal of Health Planning and Management.

Cristina Simone is a Professor of Business Management at the Department of Management at Sapienza Università di Roma. His teaching and research interests focus on different issues dealing with the innovation process within organizations. Innovation, organizational learning and entrepreneurship are frequent topics in his research. He has published his findings at journals such as TQM Journal, International, Journal of Environment and Health, World Wide Web or Journal of Management and Governance.

Rafael Fernández is a Professor in Business Management at the Department 'Juan José Renau Piqueras' at University of Valencia. He is specialised in Human Resource Management and leadership. He has published his results in journals such as Personnel Review, Journal of Business Research, Employee Relations or International Journal of Manpower. 